\title{
Exploring the State of Unbalance within the Topical and Heterotopical Spaces at the Core of Story
}

\author{
Mahshad Jalalpourroodsari (Corresponding Author) \\ Tehran University, Tehran, Iran \\ E-mail: m.jalalpur@yahoo.com \\ Sarah Catherine Household Ilkhani \\ Department of English, Shahid Beheshti University \\ P. O. Box: 1983963113 Evin, Tehran, Iran \\ E-mail: S_ilkhani@sbu.ac.ir
}

Received: 02-08- 2012

Accepted: 15-09- 2012

Published: 01-01- 2013

doi:10.7575/ijalel.v.2n.1p.68

URL: http://dx.doi.org/10.7575/ijalel.v.2n.1p.68

\begin{abstract}
This paper examines one of the ways in which narrativity as a complex concept is rooted in almost simple notions which support it at its basic levels. The discussion here would be devoted to the concept of the minimal story (récit minimal) which is defined as being part of the surface narrative syntax of every discourse in general and Ibsen's A Doll's House in particular. It will be seen how the play's content signs are converted via the minimal story and how the supporting pillars of this discourse are grounded in elementary types of narrative programmes which cement the trajectory (Note 1) of meaning at its surface stratum. The basis of this research is the semiotic theory proposed by the French structuralist semiotician Algirdas Julien Greimas as the founder of Paris School of semiotics. It will be seen how the story can arrange itself from its end and how the whole narrative process may possess a temporal and syntactic orientation which forms the bare structure around which the whole story is weaved. This paper attempts to shed some light on the inner fluctuations at the heart of Ibsen's play accommodating an orientational schema which the semioticians would call the nucleus of all narrative systems. Therefore, in this article, an introduction of the basic concepts will be followed by an analysis of the turbulences affecting the main figures/actants (Note 2) inhabiting the minimal story of Ibsen's discourse.
\end{abstract}

Keywords: Minimal Story, Permanence, Change, Correlated Contents, Temporal/Thematic Axis, Inversed/posited Content, Topical/Heterotopical Space

\section{Introduction; Minimal Story (Récit Minimal):}

An ideal story commences with a stable situation which a force comes and perturbs.

It results in a state of unbalance. Thus a force in the opposite direction is needed to reestablish the balance. The second equilibrium is similar to the first one but the two are never identical. (Todorov cited in Adam, 1994, p. 31) (Note 3)

In order to explore the arrangement of the constituent parts within a semiotic object, which is being analyzed based on its mode of production, one could use the concept of the generative trajectory (Parcours Génératif), which takes one from a profound, abstract stratum of the discourse to more concrete ones. The semio-narrative structures are positioned at the deepest layer of this trajectory, and have syntactic and semantic components, and are in turn sub divided into two different levels of depth. The deeper level is denominated as the deep level, containing a fundamental syntax and a fundamental semantics, and the surface level in turn contains a surface narrative syntax and a narrative semantics (Greimas \& Courtés, 1993, p. 158-159). The minimal story which is the focus of this research is positioned in the surface narrative syntax of discourse. (Note 4)

In the semiotics of action, in every discourse, independent of the form and the manner in which it is moulded and then presented, there is a story which in a very general way gives one a wide perspective over the whole action, and summarizes in a systematic, conventional way, the main fluctuation at the heart of the narrative. This "semiotic structuration" (Bertrand, 2000, p. 178), would present one with the pattern based on which, or for which, the whole story has been designed. Besides, more importantly it gives the gist of the main transformation, connected to the main figures involved in the action.

To look at the discourse from such a point of view, is to adopt a global scope towards the narrativity (Courtés, 1991, p. 36 ), one based on the "current opposition between the permanence and the change (changement) ... it is thanks to this 
fundamental distinction between what is stable and what is modified that we give meaning to all the things which constitute our semantic universe" (p. 36). Therefore the disparity and the inconsistency at the heart of the narrative grow into its final congruity and oneness. Sometimes permanence is referred to as static state, while the change is referred to as dynamism. One should also not neglect the fact that permanence and change are regarded as "the two complementary and opposed faces of the same datum, they mutually refer to one another" (p. 36), so much so that apart from their interrelation, it would be hard to give any exact definition for them (p. 36). When it is said that they are the faces of the same datum, it only confirms the idea recurrent in semiotics that one cannot talk about the difference unless there exists a "resemblance ... a common trait" (p. 37) and it is this resemblance that creates the harmony and the coherence of the discourse. In other words, "if there were no relationship between the initial state and the final one, the addressor of the discourse would be lost" (p. 37). In Maupassant; la sémiotique du texte (1976), Greimas sees the formation of the minimal story as one of the ways in which the isotopy (Note 5) of the discourse could be felt, since "the conversion is not situated inside one single actor, the new isotopy of the text is applied to the text" (p. 106) in its totality.

Of the two parts already mentioned, "the emphasis is put on the change as opposed to the permanence ... or on the passage as opposed to the states" (Courtés, 1991, p. 36-37), because the important thing from the perspective of the semiotics of action is that "something happens [between] the initial unbalance and the final balance" (p. 36). To put the stress on the mediative part in the middle, would be to give the definition of the story as "a transformation situated between two successive and different states" (p. 37). Talking about the successional nature of the states leads one to understand that there could be no story unless there were a relationship between a before (avant, l'amont) and an after (après, l'aval) (p. 37). In fact, if the story is to be considered as possessing any signification or meaning, it should be read in terms of a simple semantic structure with a temporal dimension (Greimas, 1981, p. 35). As the story goes forward alongside its temporal axis, what happens is a "reversal of the situation which is ... nothing more than the inversion of the content signs" (p. 35-36). In terms of syntagmatic utterances, one could say that the minimal story is made by the opposition between the "inversed content, when the subject of state is disjoined from its object of value, and the posited content, when the subject of state is conjoined with its object of value" (Adam, 1994, p. 95). These two contents are also called "correlated contents" (Greimas, 1981, p. 36), and this correlation is defined in terms of the transformational relation existing between the two in that the one corresponding to the initial sequence gets reversed, and the newly framed final sequence is posited. However, the important point to remember is that almost all the time "the content changes but only partially" (p. 41), so that the later formed meaning has the same essence of the previous one while at the same time being its opposite. Greimas summarizes this "framework (armature), which forms the structural status of the discourse" (p. 35), in a diagram which gives the "presumed articulation of the content" (p. 43):

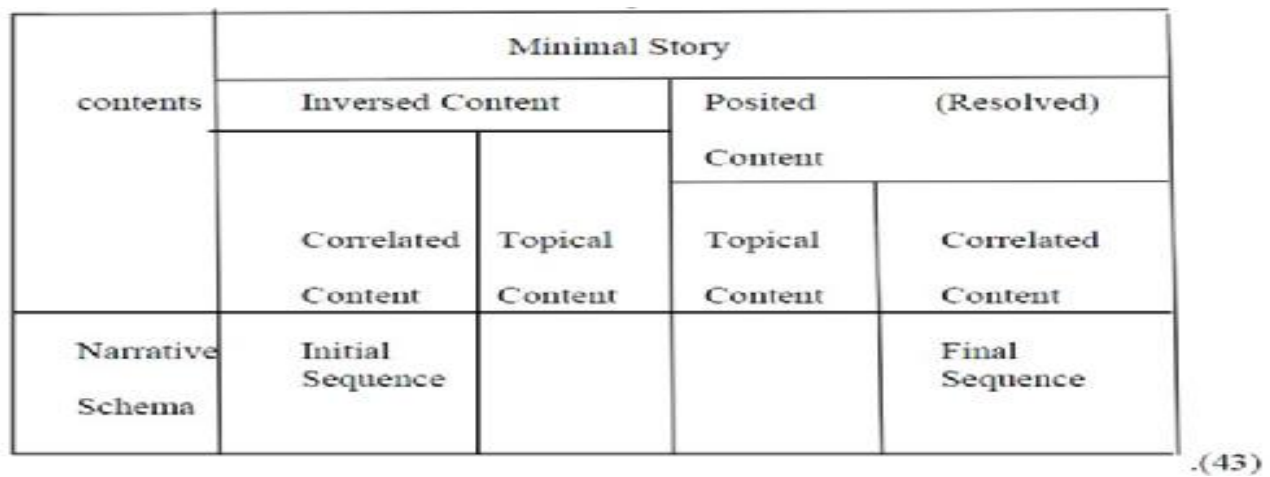

Figure 1. Structural Status of the Discourse

According to this model it can be inferred that such a definition "cuts up the story in its most basic sequences" (p. 43). Besides, as is seen in the diagram, a "temporal opposition is correlated with a thematic opposition; before/after, inversed content/posited content" (Bouissac, 1998, p. 442). It is seen that as the story goes forward in time, its initial inversed content becomes the final posited one while the same texture and essence remains intact throughout the whole discourse. In fact, the whole point of the story is determined "retrogressively [when] ... the end determines what precedes it" $(p, 442)$ in that the story can be read from its very end when its resolved state has always been reigning the macro and micro universes of what comes before it all the time. As is evident from this structuration, it could be stated that the "boundaries (bornes)" (Adam, 1994, p. 207) of the discourse should be fixed if the story is to be seen as being complete and "the narrative demonstration" (p. 207) is to be reproduced. The model presented above is, according to Bouissac (1998) "a unifying, global model of the abstracted narrative, which illustrates only formal and invariant properties" (p. 442), and helps one link the syntagmatic structures of the narrative with its semantic counterparts. The diagram presented by Adam in his Le texte narratif (1994) is founded on the same laws, only the shape of his presentation is slightly different from that of Greimas's, and it goes as follows:

$\begin{array}{ccccc}\text { Before } & \rightarrow & \text { Transformation } & \rightarrow & \text { After } \\ \text { Inversed Content } & \rightarrow & \text { Events } & \rightarrow & \text { Posited Content } \\ {[\mathrm{S} \cup \mathrm{O}]} & & \rightarrow & & {[\mathrm{S} \cap \mathrm{O}] \quad \text { (p. 207) }}\end{array}$


Adam believes that this diagram permits one to look at the story as the "transformation of the qualifying predicates, underlined by the subject-object relations" (p. 207). It should be useful at this point to know that Greimas in his Maupassant; la sémiotique du texte (1976) has added to the binary temporal category of /Before/ vs. /After/, such as presented above, in that he talks about /During/ (Pendant), and explains that "/during/ is the time in which the narrated events are inscribed" (p. 20). So basically, the logic remains intact, only Greimas has come up with another terminology to describe the transformative state of the minimal story, or as he himself states "a temporal framework ... which establishes an assured frontier" (p. 20-21) in the text. He even uses other terminologies, referring to the same concepts such as "/Precedence/ vs. /Concomitance/ vs. /Posterity/" (p. 71), and he furthers his propositions in that he even names the narrative spaces within which each of these phases takes place, he defines the "topical space (espace topique), as the place where the transformation in question finds itself manifested syntagmatically, and the heterotopical spaces (espaces hétérotopiques), as the places which surround the former space with either preceding or following it" (p. 99). These spaces have nothing to do with the actual places presented in the course of the narrative, they are spaces in the discourse, in that the unfolding of the narrative programmes (Note 6) happens in the topical space, and the two basic utterances of state as belonging to the minimal story, happen in the heterotopical spaces.

Confirming what Bouissac had already talked about, Adam cites from Claude Chabrol who thinks that "the story arranges itself from its end, going back to its beginning, so logically the last given unit is the first one" (cited in Adam, 1994, p. 207). This is important in understanding that all that happens within the story eventually aims to bring about the final state, so it would be as if first there is a final state, and for its realization all the semiotics of action is put into place. This way of organization is much more global than one might think, in that it is even found in the "mental constructions which one elaborates" (Courtés, 1991, p. 36), thus to find it in any discourse is only natural.

Based on what has been said up to here one could also come up with the very "basic schema ... with the following orientation:

$$
\{\text { state }=[\text { état }] \quad \mathrm{T}=\text { transformation }\}
$$

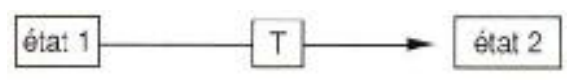

Figure 2. Elementary Narrative Organization

which manifests the elementary narrative organization" (p. 38) in a general sense. Such a formulation of the story, gives one the basic sequence within the discourse (Adam, 1994, p. 98). Even by a glimpse at this schema, one could see that the two states at the beginning and the end of the discourse "logically frame" (Courtés, 1991, p. 38), the whole narrative and that the whole process possesses a relation of "orientation" (p. 39), meaning that there is a "temporal component at the formal basis" (p. 39) of every story.

This minimal story is the part which "establishes the general structure of the narrative phenomenon, by taking into consideration the syntactic forms of the states" (Bertrand, 2000, p. 178); but these states would come only in their logical skeletal frame (p. 178) which could be analogical to the form they take in the narrative programmes. The order in which this story would appear is paradigmatic (p. 178), since one state is altered through certain developments in the story, giving way to alternative ones, and these states are not present all at the same time within the discourse. In fact, the "syntagmatic progress of the story" (p. 178), meaning the sequence of the narrative programmes embedded in the canonical narrative schemas, "reveal a more profound structure on which it reposes" (p. 178), and by this profound structure Bertrand means the minimal story. It is important to know that this paradigmatic structure comes way before the syntagmatic one (p. 178), because it would be like the "veritable architecture of the narrative" (p. 178), the bare structure around which the narrative is weaved.

What is implied in the concept of the minimal story, is that the "states are constituted of the state predicates (prédicats d'état) (Note 7) of having and being (avoir et être) ... while the transformation phase is reposed on the predicates of doing (prédicats de faire)" (Bertrand, 2000, p. 178). Thus, it can be seen that it is the basic states and their way of structuring that holds up the whole narrative structure and creates the narrativity (p. 178), not as one might think "the presuppositions about the action" (p. 178). This is why according to semioticians the minimal story is considered to be the "nucleus of all narrative systems" (p. 178), in that there is only talk about a story when "two utterances of state are governed and transformed by one or more utterances of doing" (p. 178). Therefore, it is possible to "link up this syntactic formulation, founded on the transformation of a state into another contrary state through the mediation of a state of doing, to the more profound formulation of the elementary structure" (p. 178-179) of the narrative.

In most cases, what one perceives in this elementary form, is a progress or "the change in state which consists of a passage to a superior degree level" (Bertrand, 2000, p. 202). This definition also happens to correspond to one of the definitions of the narrative programme of conjunction (p. 202) when the subject reaches the object from which it has been deprived for long. So to put it in another way, the progress is the "lexical manifestation of the elementary narrative structure: state1- transformer doing- state2" (p. 202), in other words the bringing to surface of the profound creative processes at work within the narrative. These processes would "play with the relation between the subject actant and the object actant, defined reciprocally by their junction, either their dis-junctions or their con-junctions" (p. 202).

Courtés in his Analyse sémiotique du discours (1991) provides one with a new dimension of the basis of story in that to him the story consists of "going from state 1 of /ignorance/ to the state 2 of /knowledge/, and in syntactic terms one would say that a given subject S2, first disjoined of its object /knowledge/, is then conjoined with it: $(\mathrm{S} 2 \cup \mathrm{O}) \rightarrow$ 
$(\mathrm{S} 2 \cap 0)$, these are the two narrative states, the initial and the final one" (p. 120). The whole argument presented above can lead to a more thorough appreciation and a better perception of the complexly woven world of Ibsen's A Doll's House. It will be seen how elementary types of narrative programmes cement the trajectory of its meaning at its surface stratum.

\section{The Focal Fluctuations at the Heart of the Minima Story of Ibsen's A Doll's House:}

In the beginning of the story, if one considers the primal semantic relation that exists between the two main figures of the discourse, Nora and Torvald, it can be inferred from their hierarchical relationship, that Torvald is the agent, while Nora occupies the patient's position, in that she is the one who is influenced by him. Nora is seen as one who is used to getting her competence from her husband, in a stable static state, which might even have looked quite ideal from an external angle of view, but which emptied her innate capacities from inside. Such is the heterotopical space in which Nora and Torvald find themselves initially. This is the leading state which is characterized by a qualifying predicate of having (predicat d'avoir) constituting her inversed content (original state). This early status of hers can equally be defined syntagmatically. In order to present a syntagmatic representation of Nora's condition at this point, it will suffice to see how she is displaced from her self (Nora $\cup$ Sense of Self/Knowledge), along with all that qualifies a person as a whole. She has been detached from her independence, individuality, or self-worth, in that her self was defined by an outer force (Torvald and his beliefs). Her sense of being was ascertained in terms of submission and obedience, and not through her own will as a person because at this point she was disjoined from the truth of the situation in which she lived. This inaugural stage on which Nora and Torval perform is one on which she enjoys no liberty of her own which is completely conspicuous in her state of domestic impotence in her even having to answer to and get permission from her husband for the simplest of things like eating "macaroons" (Ibsen, 1954, p. 29). Moreover, in this enslaved subordinate position, the wife would acquire no option but to resign to the agent's verdicts, through affirming them all the time saying "Oh, yes Torvald" (p. 26) or trying to make him pity her through imploration as when she implores him to "let [them] squander a little, now- just the least little bit!" (p. 26).

However, the situation does not remain the same for too long. The force perturbing the introductory balance in the story comes through gradually. It penetrates Nora's mind from within, when she starts to challenge the force which had sent her to such degrading corners. She goes through revelatory phases and gains comprehension of her past life, an awareness which is evident in her words to Torvald telling him that:

Nora: No; ... And you have always been so kind to me. But our house has been nothing but a

playroom. Here, I have been your doll - wife, just as at home I used to be papa's doll-child. And

the children, in their turn have been my dolls. I thought it fun when you played with me, just

as the children did when I played with them. That has been our marriage Torvald. (p. 101)

This opposing force which eventually fluctuates the roles of these two actants, is an externally stimulated yet an innergenerated and inner-directed one, which resonates outer-directedly when Nora as the subject turns into a performative one, and as the story goes forward temporally, she treads consistently on a path towards a for-better modification in terms of content, in that as the main figure in the action of the story, she goes from state1 of /ignorance/ and /subordination/ to the state2 of /knowledge/ and /independence/, and for this cardinal transformation to happen within the heterotopical borderline spaces of this narrative, the entire action is put in the middle of these two successive contrary but complementary situations. She is the story's main subject of state, the one for whose change of status, into a more euphoric one, or it would be better to say, the one for whose progressive trajectory, the story is retrogressively unfolded, and the trajectory has got into motion, obtaining a sense compatible with that of each and every part of its constituent parts, which in a cohesive manner state and restate the signification, distributing it throughout the whole discourse while at the same time scaffolding the isotopy of the text.

The unfolding of the story takes place in the mediatory section of the topical space forming the "narrative macroproposition" (Adam, 1994, p. 40), or the ensemble of all the actions inscribed in this milieu as the "base of the [major] transformation" (p. 40) that Nora as the main actant goes through. What is of importance here is the fact that all of the programmes and discursive events happening after Nora's conjunction with her dysphoric primal state, envisage and facilitate the ultimate dynamic shift in the relations of the two afore mentioned actants, while at the same time framing the global scope of the interior design of Ibsen's narrative. his narrative macroproposition is "composed of several narrative micropropositions" (p. 40) such as Nora's secretive debt to Krogstad, her futile attempts to get out of her debt and then to conceal her secret from a seemingly devoted and protective husband which eventually led to unmasking Torvald's hypocritical act of love. Whatever happens at this point within the story, or at this topical space, is considered to be the events of the story, which "come and break off the first situation" (p. 40). Such events are looked upon as utterances of doing which succeed and govern the initial qualifying predicate of state or Nora's primary condition. The events also bring about the inversion of the content signs, which is manifested syntagmatically as the following ameliorated posited content: (Nora $\cap$ Knowledge). The main mediatory program/event which breaks the calm universe of A Doll's House, is Nora's seeing through Torvald's deceptive state. She becomes disillusioned when she understands that Torvald would not be willing to sacrifice anything for his family. In her delusive state she had the conviction that he would take the blame for the forgery she had committed to save his life by borrowing money from Krogstad. Nora's credulity was in particular based on Torvald's having already declared that he "wished some danger might threaten [her], that [he] might risk body and soul and everything for [her] dear sake" (Ibsen, 1954, p. 95). However, Torvald breaks her trust and she starts to get out of her immature position when she notices that he has never had any intention of sacrificing himself when he declares his firm belief that "no man sacrifices his honour, even for the 
ones he loves" (p. 105). Therefore, after receiving the revelatory letter written by Krogstad unveiling Nora's secret, Torvald senses the threat of being humiliated due to his wife's conduct and thus he drops the act and unveils his real inconsiderate self in calling her "a hypocrite, a liar, worse worse a criminal" (p. 96), and puts all the blame on her for having "ruined [his] future" (p. 96), instead of trying to bear her problem upon himself.

Therefore, Nora eventually comes to know that her primary situation, no longer suits her, and that she has to complete the towards-not-male-dominance process that she had started. In the end she decides to "stand quite alone ... and know [herself] and [her] surroundings; [when she] cannot stay with [the husband] any longer" (Ibsen, 1954, p. 102), and leaves his male dominance, along with her own female subordination behind. She even exteriorizes this private change of her state by announcing that "[she] [is] going at once. ... It is of no use [he] forbidding [her] anything now. She shall take with [her] what belongs to [her]. From [him] [she] will accept nothing, either now or afterwards" (p. 102). This time, it would be the female who has obtained the unconditional upper hand, and has given the verdict in saying that she "no longer believes in miracles" (p. 107).

Finally, at this point the situation is reversed and the final boundary making heterotopical space is achieved. A space in which Nora relies no more on Torvald, but on her newly-found self. A space where she inverses the content of the discourse by surrendering no more to baseless imposed expectations of Torvald and her entourage. She frees herself from her husband, her children, her earlier role of a doll and everything which had the potential to confine and define her. She is released into a novel domain where she can conjoin the euphoric values of /freedom/ + /non confinement/ through her positive journey. However, the main fluctuation in the line of this discourse would have not been possible, had it not been for her realizing the fake nature of her husband's claims. In the end Nora understands that Torvald "has never loved [her], but only thought it amusing to be in love with [her]" (Ibsen, 1954, p. 101), and that through trusting a person who "has never understood [her]" (p. 100), she has done an "injustice" (p. 100) to herself. She "takes off [her] masquerade dress" (p. 99) and leaves her previous values, which have now proven to be invested with dysphoric nature for her and moves on towards more euphoric values in a heterotopical space where she would be able to "exchange serious word[s] about serious things" (p. 100).

Therefore, as the discourse approaches its closing lines, one sees Nora positing novel content signs, and new values such as freedom and self-respect to which she adheres, and thus signals the final boundary of discourse which encloses the abstract narrative demonstration as the story ends. She gets conjoined with these values from which she has been deprived during her married life, and even before that. This is the dynamism and fluctuation of which Greimas talks in the narrative, when the story becomes analogical to a flowing river, which is oriented towards its final phase, and that without the presupposition of such movements in its course, there would exist no story at all. If all that the story offered was a permanent state, with no change, then there would be no sense of time, no temporal axis, based on which one could get a sense of beginning and closure, which is essential to have a story.

However, one should be reminded of the fact that although Nora's situation has changed, it has only changed partially, since she moves alongside the same axis: In fact, /ignorance/ and /awareness/ are "the two extreme poles of the same axis" (Courtés, 1991, p. 37) of awareness, and consciousness, as its common trait. So the coherence of the discourse is maintained. If one were to use Adam's diagram, the minimal story of $A$ Doll's House would look something like this:

$\begin{array}{lccc}\text { Before } \rightarrow & \text { Transformation } & \rightarrow & \text { After } \\ \text { Inversed Content } \rightarrow & \text { Events } & \rightarrow & \text { Posited Content } \\ \text { /Ignorance, Lack of Awareness/ } & \text { Ensemble of } & \text { /Awareness/ } \\ \text { [Nora } \cup \text { Awareness, Knowledge }] & \text { Events of the Story } & {[\text { [Nora } \cap \text { Awareness, ] }} \\ & & {[\text { Nora } \cap \text { Knowledge] }}\end{array}$

\section{Conclusion}

Thus, it can be seen that at the end of the story, Nora [S] finds herself conjoined [ $\cap$ ] with her object of value [O], from which she has been previously disjoined $[\cup]$. Hence, an improvement is seen in her status, which ratifies the belief that the story usually moves towards a better state of affairs. Therefore as the minimal story testifies, Nora's progress is the nucleus of Ibsen's narrative system, as its major objective, and the story becomes a tableau, portraying the tracks which have been collaboratively covered by the actants of narration in the topical space, in the form of narrative programmes, all of which orbiting around this unifying center which retrospectively supplies them with signification. This perspective also shows the border lines inside the discourse where a thin line can be rawn between the middle topical space, and the framing heterotopical ones which come before the start of the main action and after it has been completed, and motivate the entire action of the story. A good summary of what has been discussed by now, could also be demonstrated by the schema introduced by Greimas himself: 


\begin{tabular}{|l|l|l|l|l|}
\hline \multirow{2}{*}{ contents } & \multicolumn{4}{|c|}{ Minimal Story } \\
\cline { 2 - 5 } & Inversed Content & \multicolumn{3}{|c|}{ Posited (Resolved) Content } \\
\cline { 2 - 5 } & $\begin{array}{l}\text { Correlated } \\
\text { Content }\end{array}$ & Topical Content & Topical Content & Correlated \\
Narrative & $\begin{array}{l}\text { Initial } \\
\text { Sequence }\end{array}$ & $\begin{array}{l}\text { Content } \\
\text { awareness) }\end{array}$ & (Nora nawareness) & $\begin{array}{l}\text { Fequence } \\
\text { Schal }\end{array}$ \\
\hline
\end{tabular}

Figure 3. Structural Status of A Doll's House

\section{References}

Works in English and French:

Adam, J. (1994). Le texte narratif. Paris: Nathan.

Arup, J. (1966). Narrative and Symbol in Ibsen. In James Walter McFarlane (Ed.), Discussions of Henrik Ibsen (pp. 99103). Boston: D. C. Heath and Company.

Averill, J. (1988). About Greimas and the Nature of Meaning: Linguistics, Semiotics, and Discourse Theory by Ronald Schleifer. Rocky Mountain Review of Language and Literature, 42 (4), 252-253.

Bentley, E. (1966). Ibsen, Pro and Con. In James Walter McFarlane. (Ed.), Discussions of Henrik Ibsen (pp. 11-18).

Boston: D. C. Heath and Company.

Bertrand, D. (2000). Précis de sémiotique littéraire. Paris: Edition Nathan HER.

Bouissac, P. (1998). Encyclopedia of Semiotics. New York: Oxford University Press.

Bressler, C. (2007). Literary Criticism: An Introduction to Theory and Practice. New Jersey: Pearson Education.

Bronwen, M, \& Felicitas, R. (1998). Key Terms in Semiotics. London: British Library Press.

Champagne, R. (1977, Feb.). About Maupassant la sémiotique du texte: exercices pratiques by Greimas. The French Review, 50 (3), 501-502.

Chandler, Daniel. (2002). Semiotics: The Basics. New York: Roultledge.

Cobley, P. (2007). The Routledge Companion to Semiotics and Linguistics. New York: Routledge.

Courtés, J. (1976). Introduction a la sémiotique narrative et discursive. Paris: Hachette.

Courtés, J. (1991). Analyse sémiotique du discours: de l'énoncé à l'énonciation. Paris: Hachette Supérieur.

Davis, R. C. (1984, Dec.). About Sémantique structurale. MLN, 99 (5), 1211-1215.

Ellis-Fermor, U. (1966). Ibsen and Shakespeare as Dramatic Artists. In James Walter McFarlane (Ed.), Discussions of Henrik Ibsen (pp. 89-98). Boston: D. C. Heath and Company.

Graham, J. (1978, Winter). Semiotics and Semantics. Boundary, 2 (3), 591-598.

Greimas, A., \& Joseph,C. (1993). Dictionnaire raisonné de la théorie du langage. Paris: Hachette Livre.

Greimas, A. J. (1971, Dec.). Narrative Grammar: Units and Levels. (Philip Bodrock, Trans.). MLN, 86 (6), $793-806$.

Greimas, A. J. (1976a, Spring). The Cognitive Dimension of Narrative Discourse. (Michael Rengstorf, Trans.). New Literary History, 7 (3), 433-447.

Greimas, A. J. (1976b). Maupassant la sémiotique du texte: exercices pratiques. Paris: Seuil Edition.

Greimas, A. J. (1977, Spring). Elements of a Narrative Grammar. (Catherine Porter, Trans.). Diacritics, 7 (1), $23-40$.

Greimas, A. J. (1981). Eléments pour une théorie de l'interprétation du récit mythique. In Seuil (Ed.), Communications 8:Analyse structurale du récit (pp. 34-65). Paris: Seuil.

Greimas, A. J. (1983). Du sens II: Essais sémiotiques. Paris: Seuil.

Greimas, A. J. (1986). Sémantique structurale. Paris: Les Presses Universitaires de France.

Greimas, A. J. (1989a, Spring). The Veridiction Contract. (Frank Collins, \& Paul Perron, Trans.). New Literary History, 20 (3), 651-660.

Greimas, A. J. (1989b, Spring). On Meaning. (Paul Perron, \& Frank Collins, Trans.). New Literary History, 20 (3), 539 550 .

Greimas, A. J. (1989c, Spring). On Narrativity. (Paul Perron, \& Paul Riceur, \& Frank Collins, Trans.). New Literary History, 20 (3), 551-562.

Haakonsen, D. (1966). Ibsen the Realist. In James Walter McFarlane (Ed.), Discussions of Henrik Ibsen (pp. 70-82). Boston: D. C. Heath and Company.

Harris, R. (1989, Nov.). About Greimas and the Nature of Meaning: Linguistics, Semiotics, and Discourse Theory by Ronald Schleifer. The Review of English Studies, 40 (160), 541-542.

Howells, W. D. (1906, Jul.). Henrik Ibsen. The North American Review, 183 (596), 1-14.

Ibsen, H. (1954). A Doll's House. In William Archer (Ed.), Four Plays: A Doll's House- The Wild Duck- Ghosts- The Master Builder (pp. 25-107). (William Archer, Trans.). London: Thomas Nelson and Sons Ltd.

Lechte, J. (1994). Fifty Key Contemporary Thinkers: From Structuralism to Postmodernity. New York: Routledge. 
McFarlane, J. (1966). Revaluations of Ibsen. In James Walter McFarlane (Ed.), Discussions of Henrik Ibsen (pp. 1927). Boston: D. C. Heath and Company.

Makaryk, I. (1993). Encyclopedia of Contemporary Literary Theory: Approaches, Scholars, Terms. Toronto: University of Toronto.

Marker, F, \& Lise-Lone Marker. (1989). Ibsen's Lively Art: A Performance Study of the Major Plays. $\quad$ Cambridge: Cambridge University Press.

Mencken, H. L. (1966). The Technical Quality of the Plays. In James Walter McFarlane (Ed.), Discussions of Henrik Ibsen (pp. 7-10). Boston: D. C. Heath and Company.

Meyer, M. (1971). Ibsen: A Biography. London: Cox and Wyman Ltd.

Mitchell, B. (1977, Summer). About Maupassant la sémiotique du texte: exercices pratiques. World Literature Today, $51(3), 414$.

Miller, A. (1966). The Real in Ibsen's Realism. In James Walter McFarlane (Ed.), Discussions of Henrik Ibsen (pp. 104-105). Boston: D. C. Heath and Company.

Nef, Fredric. (1977, Spring). Introduction to the Reading of Greimas: Towards a Discursive Linguistics. Diacritics, $7(1), 18-22$.

Noth, W. (1990). Handbook of Semiotics. Indiana: Indiana University Press.

Peacock, R. (1966). Effects of Ibsen. In James Walter McFarlane (Ed.), Discussions of Henrik Ibsen (pp. 106-110). Boston: D. C. Heath and Company.

Perron, P. (1989, Spring). Introduction: A. J. Greimas. New Literary History, 20 (3), 523-538.

Ricoeur, P., Collins, F., \& Perron, P. (1989, Spring). Greimas's Narrative Grammar. New Literary History, 20 (3), 581608.

Roe, F. (1905, Jul.). Ibsen as a Dramatist. The Sewanee Review, 13 (3), 305-318.

Ferdinand de, F. (1972). Cours de linguistique générale. Paris: Edition Critique Payot.

Schleifer, Ronald. (1987). A. J. Greimas and the Nature of Meaning: Linguistics, Semiotics, and Discourse. New South Wales: Providence House.

Seldon, R, \&Widdowson, Peter (1993). A Reader's Guide to Contemporary Literary Theory. London: British Library Cataloguing.

Segre, Cesare, \& John Meddemmen. (1989, Spring). The Style of Greimas and its Transformation. New Literary History, 20 (3), 679-692.

Shaw, G. (1966). Henrik Ibsen: The Lessons of the Plays. In James Walter McFarlane (Ed.), Discussions of Henrik Ibsen (pp. 1-6). Boston: D. C. Heath and Company.

Tyson, Lois. (2006). Critical Theory Today: A User Friendly Guide. Florida: CRC Press.

Van Dijk, Teun. (1972). Aspects d'une théorie générative du texte poétique. In A. J. Greimas (Ed.), Essais de sémiotique poétique (pp. 180-205). Paris: Larousse.

Waugh, P. (2006). Literary Theory and Criticism. New York: Oxford University Press.

Williams, R. (1966). Ibsen's Non-Theatrical Plays. In James Walter McFarlane (Ed.), Discussions of Henrik Ibsen (pp. 35-38). Boston: D. C. Heath and Company.

Wolfreys, J. (2001). Introducing Literary Theories: A Guide and Glossary. Edinburgh: Edinburgh University Press.

Works in Persian:

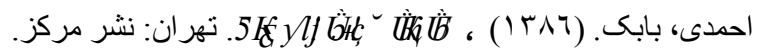

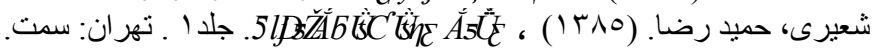

\section{Notes}

Note 1. Progression from one point to another point (Greimas \& Courtés, 1993, p. 269).

Note 2. Actants are defined as being the permanent, invariant roles, which are given preeminence at the deep structure of the narrative and are positioned and arranged in the narrative programmes (Boussiac, 1998, p. 5).

Note 3. All translations from French are my own, unless stated otherwise.

Note 4. Discourse is generally identified with the "semiotic process" (Greimas \& Courtés, 1993, p. 248-249).

Note 5. The basis of the semantic isotopy is the "recurrence of the semic categories" (Greimas \& Courtés, 1993, p. 197) which have "Semic proximity" (Courtés, 1991, p. 114). The semantic isotopy guarantees the "internal coherence of the object under scrutiny" (p. 104) and provides a uniform reading.

Note 6. The narrative programme is a [syntagmatic] function, by which a subject of doing does something so that the subject of state finds itself disjoined of an object to which it had been conjoined, or inversely (Bertrand, 2000, p. 184). Any PN thus contains two sorts of utterances, "utterance of doing and utterance of state" (Greimas \& Courtés, 1993, p. 297), as its "basic utterances (énoncés de base)" (Bertrand, 2000, p. 183), which would come together in the following forms, "constituting an algorithm of transformation" (p. 183):

$\mathrm{PN}=\mathrm{F}[\mathrm{S} 1 \rightarrow(\mathrm{S} 2 \mathrm{Ov})] \quad \mathrm{PN}=\mathrm{F}[\mathrm{S} 1 \rightarrow(\mathrm{S} 2 \mathrm{Ov})]$

Note 7. ( $\mathrm{S} \cap \mathrm{Ov})$ OR (S2 $\cup$ Ov) ov: object of value (Greimas \& Courtés, 1993, p. 297). 